\title{
Teacher Preparation at the University of Zambia: Is Peer Teaching Still a Useful Strategy?
}

\author{
Peter Chomba Manchishi, David Sani Mwanza
}

School of Education, University of Zambia

\begin{abstract}
Peer teaching or micro teaching is a common practical exercise in teacher education programmes yet its usefulness is under continuous study. Like in many other teacher education programmes, peer teaching is an activity where student teachers practice to teach in a made up classroom in which peers act as learners as well as observers. This study sought to establish whether or not, peer teaching was still a useful technique in introducing student teachers to practicalities of teaching. A qualitative method was used and 16 teacher educators and 40 final year students were interviewed. The study established that while peer teaching was useful, its implementation was faced with a lot of challenges and inconsistencies which made it less effective. Other than suggesting how peer teaching can be strengthened at the University of Zambia, the study also suggests other strategies which can work in tandem with peer teaching in order to strengthen teacher education at the University.
\end{abstract}

Keywords: Peer Teaching, Strategy, Teacher Preparation, Student Teacher, Teacher Education, Teacher Educator, University of Zambia.

\section{BACKGROUND OF THE STUDY}

Originally, Peer teaching was developed in the 1960's by Dwight Allen and his colleagues at the Stanford Teacher Education Programme (Cruickshank et al., 1996). It started as a simulation activity aimed at helping student teachers to learn how to teach (Allen, 1967). It was organised as a brief practical exercise in which student teachers put teaching theory into practice. Student teachers were asked to plan and present a 5 to 10 minutes lesson in which they would apply the instructional materials learnt in lectures (Allen and Eve, 1968). Student teachers presented their lessons before a small group of their peers and the whole lesson was recorded for further viewing, reflection and evaluation by the student teachers, fellow student teachers and teacher educators (Murtiana, 2012; Trott, 1976 and RALPH, 2014). Today, where peer teaching is used as one of the teacher training techniques, the practice serves the purpose of expanding the scope and mastery of various teaching skills and orients student teachers to gain teaching experiences in preparation for natural classroom teaching (Amobi, 2005). According to Kavanoz and Yuksel (2010), one of the effective ways of acculturating teachers into their profession is through peer teaching.

Peer teaching can be understood as a practice in which peers instruct each other in a purpose-driven, meaningful interaction (Bradford-Watts 2011). Most teacher training programmes (Zambian inclusive) have both experienced and unexperienced teachers. In this set up, both experienced and inexperienced teachers learn together and help each other understand the practice of teaching in an interactive manner. In some cases, peer teaching can involve student teachers identifying topics which they consider difficulty and they teach each other on how to handle such topics in a classroom situation. Kalkowski (2001:4) noted that peer teaching manifest itself in different forms and is referred to by different names such as "peer tutoring, ... cross-age tutoring, ... peer teaching, peer education, partner learning, peer learning, child-teach-child, ... learning-through-teaching, ... [and] mutual instruction". It is also called micro teaching. Despite peer teaching having other labels, Bradford-Watts (2011) argues that what peer teaching programmes have in common is Vygotskian proposition that learning takes place through negotiation of meaning with peers within the learning environment.

Peer teaching is normally used in teacher preparation programmes in order to introduce student teachers to the practical aspects of teaching in which case, they acquire instructional experience 
before they actually go for teaching practice or final deployment. During peer teaching, student teachers are supposed to develop effective teaching strategies (Abdulwahed and Ismail 2011).

In Zambia, peer teaching is part of the teacher education programmes. At the University of Zambia, it is used to enable student teachers put the teaching theory learnt in lectures to practice. Like in the original organisation of the exercise (see Allen, 1967), student teachers are organised into small groups where one student will act as a teacher and the rest of the group members act as learners and observers. Thus, the student teacher will plan the lesson with the guidance of a peer teaching mentor (mostly course lecturers and tutors), write a lesson plan, organise teaching materials and deliver the lesson to the group. This goes on until each group member has presented his/her lesson. It must also be added that at the University of Zambia, peer teaching is graded and the mark is added to the continuous assessment grade or continuous assessment mark (CA or CAM).

Despite peer teaching being part of the teacher education programme at the institution, its effectiveness has not been established. Hence, this study.

\section{Statement of the Problem}

The teacher education programme at the University of Zambia consists of two practical activities i.e. Peer teaching within the University and teaching practice where student teachers are attached to secondary schools to practice teaching. However, while studies have been conducted on the effectiveness of teaching practice (see Manchishi and Mwanza, 2013), no study has been done to establish the effectiveness of peer teaching as a teacher training technique. Put as a question, the research problem was; Is peer teaching as a teacher preparation strategy at the University of Zambia effective?

\section{Purpose of The Study}

The study sought to establish the effectiveness of peer teaching as a strategy for teacher preparation at the University of Zambia.

\section{RESEARCH OBJECTIVES}

The objectives of the study were to:

a. Asses the views of teacher educators and student teachers on the efficacy of peer teaching at UNZA

b. Document participants' recommendations on other strategies which can be used as part of teacher preparation

\section{RESEARCH QUESTIONS}

The study sought to answer the following questions:

a. What are the views of teacher educators and student teachers on the efficacy of peer teaching?

b. Which other strategies can be used to enhance student teachers' practical skills?

\section{LITERATURE REVIEW}

This section will review studies which have been conducted on the subject of peer teaching. Although peer teaching is referred to by different words, this study will attempt to use the word peer teaching consistently to represent such concepts as peer tutoring and micro teaching. The literature in this section will also show that while studies have been conducted on the efficacy of peer teaching as a teacher preparation technique, more contextual studies are required in order to gain understanding of how teachers are prepared in different contexts and what challenges they experience.

In the United Arab Emirates, Ismail (2011) conducted a study to establish the opinions of the student teachers of English on the benefits of peer teaching. The study used both focus group interviews and a quantitative questionnaire to collect data. The findings showed that there were a number of benefits associated with peer teaching. For example, students teachers reported that peer teaching helped them improve their language proficiency and it provided them with the opportunity to improve their jargon within the context of teaching English. This is in line with Ogeyik (2009) who argued that peer teaching does not only introduce prospective teachers to the theory of teaching but enables them to refine their own language skills which is a necessary ability in the job of a teacher. In addition to 
improving ones language skills, the study also established that peer teaching made student teachers aware of their pedagogical skills in which they discovered their teaching strengths and weaknesses. Student teachers also appreciated the feedback they got from both teacher educators and fellow trainees. They stated that the feedback helped them know their areas of competence and where they needed to improve.

As hinted earlier, Ogeyik (2009) conducted a study in Turkey whose purpose was to establish student teachers' attitudes towards peer teaching. The findings revealed that student teachers at Trakya University held positive attitudes in general. The student teachers stated that peer teaching was effective in self assessment, developing self confidence, the ability to produce and prepare teaching materials, professional development and sharpening their creativity in delivering lessons. The study further claims that peer teaching motivated student teachers towards the teaching profession, gaining the knowledge of decision making regarding differentiating course designs for different linguistic and age levels, gaining the deeper understanding of the teaching methods, lesson planning, developing new teaching strategies and that peer teaching works as a tool to bridge the gap between theory and practice. All these findings are in tandem with what Yeany, (1978), Arends, (2000) and Demirel, (2004) established in their own studies about the benefits of peer teaching.

Another study with related findings is one by Kavanoz and Yuksel (2010) where they sought to find out the impact of peer teaching on pre-service teacher training and the benefits which student teachers gained through peer teaching. Like the previous study, this study was conducted in Turkey. According to the findings, student teachers found peer teaching valuable in that it helped them to increase learning and to be reflective in the skills they acquired and displayed during peer teaching which later became useful in self evaluation when they went to schools for practicum. Peer teaching also helped student teachers observe their fellow trainees and see how methods were put to practice. They equally saw how their peers presented their lessons which helped them to prepare their own and learn how they could execute a lesson in real life situations. Through observation, they also identified what type of activities promoted learning among learners and which ones were not very effective. Thus, respondents in the study were of the view that peer teaching was a valuable exercise in preparing them for the practical aspects of the job of a teacher.

Cakır (2000) notes that peer teaching is important to enable students practice the theory learnt in a lecture to teach in a classroom situation. Thus, he adds that peer teaching is an important part of teacher training programs as it ensures that student teachers do not only master the theory but acquire practical skills too

In another study, Bakir (2014) revealed that there are a lot of benefits associated with peer teaching. He states that the positive aspects of peer teaching are that student teachers gain self confidence and experience with teaching, gain practical knowledge on how to teach a class effectively, improve communicative abilities, know planning and sequencing of the lesson, they know how to introduce, develop and conclude a lesson as well as classroom time management. To this effect, peer teaching enables pre-service teachers to know the mechanics of teaching and teaching materials mobilisation and use before they go to a real classroom.

Ralph (2014) conducted a study in Canada whose aim was to establish the effectiveness of peer teaching. Student teachers were interviewed on their perspectives on the effectiveness of peer teaching. The findings showed that although the teaching environment was not authentic, peer teaching was meant to be developmental, graduated simulation activities to help student teachers prepare for theory eventual placement in schools. Another benefit was the feedback which student teachers received after teaching and how the feedback was instrumental in helping them reflect on their teaching and improve their instructional abilities (see also Benton-Kupper, 2001; Wilkins, Shin, and Ainsworth, 2009). Other than feedback, observing fellow student teachers peer teaching was helpful in observing the strengths and weaknesses of their peers and how they could make a difference. The study also established that student teachers gained confidence and overcame their fears as teachers. They learnt how to speak in front of others which was good preparation for when they go to teach in secondary schools in authentic environments.

Although peer teaching appears to be helpful in the preparation of teachers, Stanley (1998) states that student teachers are sometimes reluctant to seriously involve themselves in peer teaching activities because of the artificiality of the classroom environment, difficulties in producing and preparing 
materials, limited time in which to deliver the peer lesson and that peer teaching was homogeneous thereby making it boring and unmotivating.

In addition, Courney et al (2008) claims that anxiety is another negative feeling student teachers normally develop. It is believed that before they teach, student teachers normally become anxious which sometimes affect their performance. However, Tobias (1979) states that if the reasons for anxiety are known, the awareness becomes useful in coming up with measures to mitigate the anxiety so that student teachers are able to conduct their peer teaching exercise without any negative feeling.

Kavanoz and Yuksel (2010) states that there are a number of challenges associated with peer teaching. These include large class size, poor physical conditions of the setting, lack of interest by student teachers and the unrealistic nature of the classroom. Large class sizes meant that there was no enough time for everyone to teach and experience peer teaching according to the set goals. Thus, the author suggests that there is need for small peer teaching classes in order to have an environment where every student teacher will have the opportunity to benefit from the exercise.

Bakir (2014) interviewed respondents about the negative aspects of peer teaching. Although $50 \%$ of the respondents stated that there were no negatives associated with peer teaching, other respondents stated that peer teaching had some weaknesses. Some of the weaknesses mentioned were that student roles were exaggerated and it was conducted in an artificial environment. Limited time, tension by peer critiques, time and effort in lesson preparation, stress when preparing the first lesson were other negatives cited by respondents. What is clear from the findings of this study is that peer teaching has both positives and negatives. It is clear that peer teaching requires more time in order for student teachers to adequately prepare and deliver their lessons. Thus, luck of adequate time poses a challenge and affects the quality and effectiveness of peer teaching. It is important to reiterate the finding about student teachers fear of peer's critiques. Student teachers found their peers very harsh in their assessment and critiquing of lessons delivered by colleagues. This caused fear both before and during lesson delivery.

In Zambia, Manchishi and Masaiti (2011), Manchishi and Mwanza (2013), Mulenga and Luangala (2015) and Mwanza (2016) all report that teacher preparation at the University of Zambia is problematic. They state that student teachers often graduate with inadequate practical skills while most of the content is irrelevant to what is taught in schools. While these studies have focused on various aspects of teacher training, none of them has attempted to consider how useful peer teaching is to developing student teachers' practical skills.

From the literature that has been reviewed in this section, it is evident that while peer teaching is meant to bridge the theory-practice gap, if some factors are not addressed, challenges can come in which affect the efficacy of the exercise. It will be shown in chapter four whether or not, peer teaching is still a useful strategy, what challenges are faced and what other strategies can be put in place to strengthen teacher preparation at the University of Zambia, a site for the current study.

\section{RESEARCH DESIGN AND METHODS}

This sections accounts for how the data was collected, analysed and presented.

\subsection{Research Design}

This is a purely qualitative research employing a case study. Polit and Hungler (1999) explain that case studies are detailed investigations of individuals, groups, institutions or other social units. A case study has one person, entity, a study of one thing; it is identified as one of the many. Therefore, this was a case study of peer teaching at the University of Zambia. Thus, of all teacher training institutions in the country, this study only focused on the University of Zambia.

\subsection{Target Population and Sample Size}

In this study, the population included all the teacher educators in the school of education (at UNZA) and all the final year students training to be teachers in the school. Using purposive sampling, 16 lecturers and 40 students were interviewed (total of 56 respondents). The 16 lecturers included two lecturers teaching methods courses for the following respective subjects: English, Mathematics and Science, Geography, History, Environmental Education, Zambian languages and Religious Education. Based on the same subjects, 5 students per subject were also sampled. The student teachers who were sampled had done peer teaching and had even done their field practicum. Thus, they were in the right position to tell whether or not peer teaching was effective. 


\subsection{Research Instruments}

The instruments which were used to collect data were Interview Guide and the Focus Group Discussion Guide.

\subsection{Data Analysis}

The qualitative approach was used to analyze verbal information that was collected from interviews and focus group discussions with lecturers and student teachers. After data was collected, it was grouped under identified themes guided by research questions and objectives. In short, thematic analysis was used to categorise and analyse the data.

\subsection{Ethical Considerations}

Informed consent was sought from the respondents. The researcher explained the purpose of the study and assured the respondent of confidentiality and anonymity both during and after the study. The researcher further assured the respondent that the findings would only be used for academic purposes and not for any other purpose. During the study, respondents were informed that they had the right to refuse or stop participating in the study at any time. In short, the researcher obtained informed consent and ensured confidentiality and anonymity of the study participants.

\section{FindingS AND DisCUSSION}

Two broad questions were asked in this study. The first question was about the usefulness of peer teaching. To answer this question, teacher educators and student teachers were interviewed and asked to state whether peer teaching was an effective strategy in teacher education at the University of Zambia.

\subsection{Is Peer Teaching Still a Useful Strategy in Teachers Training at the University Of Zambia?}

Most respondents reported that peer teaching was useful. They explained that peer teaching was meant to help student teachers translate the theory of teaching into practice (see also Ismail, 2011). They argued that since teaching was a practical job, peer teaching was a way of introducing student teachers to the practical aspects of the teaching profession. Respondents also added that peer teaching was not only about the theory of teaching but the content to be taught. During peer teaching, student teachers were required to demonstrate their mastery of the subject content they learnt and how they could appropriate it to the classroom (see also Ogeyik, 2009). Thus, according to the respondents, peer teaching was that practical activity in which student teachers taught the content using particular methods which they had learnt in their course. For example, consider the following responses from teacher educators:

It (peer teaching) helps student teachers to use the methods which they learn when we lecture them...they will also become aware of the content which they will teach in schools

Peer teaching is the practical. Students practice how to teach with the help of lecturers. So, it is very effective because by the time the student will go for teaching practice, they will have practiced how to teach. So, I can say that it is effective

As reported above, it is clear from the two respondents above that they viewed peer teaching as done at the University of Zambia effective. They believed that it practically introduced the novice teacher to the practical aspects of teaching.

Other reasons given were that peer teaching was helpful in training student teachers on material preparation and how they could use the material in the classroom. Related to the issue of material was lesson preparation and familiarity with the syllabus. Respondents stated that during lesson preparation, student teachers were required to mobilise teaching materials which were suitable to the lesson they were going to teach. They explained that material preparation was a very important skill which they needed to acquire during training and that peer teaching was the time when they learnt such skill. According to respondents, lesson preparation also involved consulting the syllabus on the content to be taught these findings are similar to findings by Ogyik (2009) and Bakir (2014). Teacher educators stated that since syllabus design was taught as a topic, during peer teaching, student teachers consulted the syllabus and as a result, they gained practical knowledge about the syllabus 
(see also Cakir, 2000). The points being raised from this discussion is that teacher educators found peer teaching effective as it introduced student teachers to the practical aspects of material preparation, lesson planning/preparation and how to us the syllabus. The following are some of the responses from some lecturers interviewed:

In lectures, we talk about lesson plan theoretically, but when they have to do peer teaching, they practically have to prepare the lesson.

During peer teaching, they also get familiar with the syllabus and the content of the syllabus since they have to read the syllabus in order to see which topic to teach. They learn how to interpret the syllabus. Peer teaching is a way of introducing student to the practicalities of lesson planning, scheming of work and records of work.

It helps student teachers to know how to look for teaching materials and how to use the board... It also helps them to know which teaching aids to use on certain topics. Some of them don't know (how to use the board) and they have to learn through peer teaching.

In addition, time management and lesson evaluation were other benefits of peer teaching which were cited by respondents. It was reported that since teaching is timed in schools, it was important that student teachers were taught how to keep and manage time in the classroom. Lesson evaluation was one of the skills which were part of the benefits of peer teaching. Most teacher educators and student teachers argued that peer teaching helped trainees to learn how to plan the lesson within time allocated but to execute the lesson within stipulated time as well. Other respondents said that since peer teaching involved observing each other when teaching, student teachers learnt a lot from each other (see also Kavanoz and Yuksel, 2010; Ogeyik, 2009; Ralph, 2014). During lesson evaluation which took place after each lesson, student teachers freely asked questions and gave feedback which was helpful not only to the presenter but themselves too (. Another respondent added that while lectures where monotonous where only the lecturer was in charge, peer teaching sessions were free and the interaction between student teachers helped them to learn from each other. Another respondent was of the view that peer teaching did not only mean that a student teacher should teach, rather, even merely observing the other student teacher teaching provided a lot of learning about the practicalities of teaching (see also Ralph, 2014 and Bakir, 2014). Another benefit which was cited was class management. Both teacher educators and student teachers mentioned that class management was a very important aspect of teaching. Thus, student teachers were also supposed to practice how they could manage pupils during the lesson and how they could attract learners' attention. The ability to speak in public and the confidence required for a teacher were some of the attributes of a teacher which student teachers were supposed to develop through peer teaching. Dressing was another aspect which they said was a benefit of peer teaching. Respondents stated that dressing was a professional issue and student teachers were advised on how to dress professionally and ethically during peer teaching. According to the respondents, peer teaching was an avenue where all these attributes were acquired and they found peer teaching really helpful. Thus, they believed that peer teaching was an effective strategy in teacher training programme.

\section{Peer teaching gives students courage and confidence to manage to stand in front of a larger class later. So, they also learn about class management.}

Even dressing, I pay attention to how they dress. So, they learn that when they come for peer teaching, they have to dress formally and I tell them that's how they should be dressing when they go to teach at secondary school.

...for me, even if someone has not taught, it is still useful. The idea is to learn from the one who is presenting. It is still useful enough.

Based on the findings above, it can be reiterated that some teacher educators and student teachers found peer teaching a useful strategy in teacher preparation. As observed from the findings, some of the reasons given for the effectiveness of peer teaching at the University of Zambia are that peer teaching helps student teachers acquire abilities of translating theory into practice, teaching material preparation, lesson planning, class management, time management, boosts confidence, lesson 
evaluation and professional dressing and mannerisms. These findings are similar to those by Benton-Kupper, 2001; Wilkins, Shin, \& Ainsworth, 2009).

Although some respondents stated that peer teaching was an effective strategy in teacher training at the University of Zambia, others said that it was not effective. A number of reasons were given to justify why they thought that it was not effective. Below are some of them:

Firstly, some teacher educators said that peer teaching was not being done under its original purpose i.e acquainting student teachers with the practicalities of teaching. Rather, they argued that peer teaching was a testing exercise in which students were graded and the marks they scored contributed to their continuous assessment. They explained that students were more interested in the grades they would obtain other than the learning that would take place. One teacher educator stated "peer teaching is for assessment. It is still bordering on assessment. No wonder, we put them in groups. When each one of them has taught and we have given them marks, we are done". According to this response, the respondent suggests that peer teaching was viewed from the perspective of assessment while the most important benefits were overlooked. It also appears that even teacher educators were more concerned with that component of assessment which equally made students focus on the grades they would score and not on the skills they should acquire after doing the peer teaching.

Secondly, respondents stated that there was not much time for peer teaching. They explained that student teachers only practiced once and that in some cases, a student teacher did not teach the whole lesson. Due to limited time, some student teachers were asked to only explain how they would teach instead of practically teaching the lesson which was the original purpose of peer teaching. This meant that although there was supposed to be peer teaching, in practice, not all student teachers did it. Some teacher educators called this type of 'peer teaching' as being theoretical and not practical. This is ironic considering that peer teaching is supposed to be an exercise where student teachers translate theory to practice. In fact, respondents added that student teachers only did peer teaching once. This means that even if they made mistakes in the first attempt, they would never have the opportunity to correct them. Commenting on the lack of adequate time allocated to peer teaching, one teacher educator stated "there is no enough time. Our students only have peer teaching once". Another teacher educator said "peer teaching is done theoretically. The time is not enough. They teach just for 10 minutes but in schools, they will teach for 40 minutes or 80 minutes. So, it (peer teaching) is not effective". From the responses, it is clear that there is little time and that in cases where students are asked to explain their lesson instead of teaching, it is not anymore peer teaching but lesson discussion.

The third challenge which is closely related to the previous one was lack of adequate teaching staff at the University which could not cope with the over enrolment. Respondents said that while the University was over enrolling students, it was not employing more staff to cope with the increasing number of students who were training to become teachers. They further explained that the problem of lack of adequate staff meant that the few needed to handle the students resulting in only allowing students to teach for 5-10 minutes in order to ensure that every student teacher had the opportunity to teach. According to respondents, this situation caused another problem which was lack of classroom space. This meant that one peer teaching class had too many students thereby making the exercise difficulty not only for the peer teacher but for every member of the classroom to have an opportunity to teach. One respondent stated "there is no space. Sometimes, we have 50 students. So, this is like a normal lecture class. In peer teaching, we need to have 20 (students) only but now with so many of them, the attention is just for each one of them to teach". Another respondent said "we have too many students, so we can't have time to give every student time for two lessons. But surely, one opportunity is not enough". Another teacher educator had the following to say "the best is to give them chance to teach more than once. But because of huge numbers of students, we are forced to allow three students to teach within one hour. In the end, we just asses them. You see, the problem is that we lecturers are few". From the responses given, it can be reiterated that peer teaching is faced with several challenges which affect its effectiveness. For example, in cases where three students teach within an hour, one wonders how much time is spent on teaching and how much is spent on getting feedback from fellow peers. This raises further questions on the quality and depth of each peer teaching exercise. Thus, one can argue that in these cases, peer teaching is done for formality and most crucially, for assessment purposes and not for practicing teaching which is the intended purpose.

Another crucial problem which was cited by both teacher educators and student teachers was lack of teaching materials. All the respondents unanimously stated that the University lacked teaching 
materials. They explained that lack of materials affected variety of materials which student teachers could use. Further, teacher educators could not demonstrate adequately how different materials can be used to teach different topics since there were no materials which they could use to do so. For example, a science teacher educator stated that the university lacked chemicals and apparatus which were required for demonstrations. He said that students graduated from the university without knowing some of the most important apparatus which they would actually be required once deployed in secondary schools. He said the following "there is the issue of materials to use. For the apparatus, it is embarrassing that we do not have CRO here but when they (student teachers) graduate and they find it in a secondary school, they can't recognise it". While the respondent stated that student teachers may not recognise the apparatus, it can be added that apart from not recognising it, they cannot use it either as they would not have acquired the practical knowledge of how to use it in a classroom. The problem of teaching materials was shared by student teachers. They were also of the view that there were no adequate books, syllabus and that the only teaching aids which were provided were manila papers. They explained that lack of teaching material posed a huge challenge and affected how well they practiced teaching. One of them stated "no materials at all. So, how can we teach using different materials?. We just talk. But in the other course, they give us manila papers which we use to write something there to stick on the board". Based on the responses from both teacher educators and student teachers, it can be reiterated that lack of teaching materials affected both the quality of peer teaching and the whole teacher preparation in general.

The negative attitude by both teacher educators and student teachers towards peer teacher was also said to be one of the reasons which made peer teaching ineffective. Respondents stated that some teacher educators held negative attitudes towards peer teaching and did not pay attention to the exercise. Other respondents also said that some student teachers held negative attitudes towards teaching and they did not put in a lot of effort in the exercise. Some respondents argued that some student teachers looked at peer teaching as unreal and they took it for granted. For example, one teacher educator said "these students are not serious. Some of them say that they don't want to become teachers, so when it comes to peer teaching, they do it just because we give grades. Otherwise, they are not interested". Another teacher educator had the following to say "lecturers are also to blame. There is the 'I don't care' attitude among some lecturers. They don't pay attention to peer teaching but they are interested in going out to observe students during teaching practice just because they get paid for teaching practice. We have a situation where they go for teaching practice and they question the quality of teachers they observe but did not do anything during peer teaching when students were still here (University)". Clearly, a successful teacher preparation programme depends on the positive attitudes of both teacher educators and student teachers. Thus, where positive attitude is lacking, the effectiveness of the programme become uncertain. In this case, the fact that some of the teacher educators and student teachers held negative attitude towards peer teaching meant that student teachers did not gain much from the benefits of peer teaching.

In conclusion, on the question of whether or not, peer teaching at the University of was still a useful strategy in teacher preparation, the answer is both yes and no. While some respondents stated that it was effective others stated that it was not. However, one point needs clarification. Those who stated that it was not effective did not doubt the usefulness of the practice itself, but how it was being conducted at UNZA. Thus, while they believed that the practice itself was important for teacher training, their argument was that its implementation at UNZA was so poor and faced with so many challenges which consequently made it ineffective. Therefore, it can be concluded that while peer teaching is still a useful strategy in teacher preparation at UNZA, its poor implementation and the challenges it faced made it less effective.

\subsection{What Other Strategies Can Enhance Student Teachers' Practical Skills at UNZA?}

In addition to finding out whether or not peer teaching was still a useful strategy in teacher training at the University of Zambia, respondents were also asked to suggest what they though could enhance the acquisition of practical skills by student teachers. This was based $n$ the belief that UNZA graduate teachers did not have enough practical skills when they were deployed to secondary schools (see Mwanza, 2016; Mulenga and Luangala, 2015 and Manchishi and Mwanza, 2013). The data was collected through face to face interviews with teacher educators and student teachers.

Both teacher educators and student teachers stated that before one could think of additional strategies, it was important that the current weaknesses of peer teaching were resolved. They argued that peer 
teaching was an important part of teacher preparation but needed improvements if it was to be effective and helpful to student teachers. All the respondents unanimously suggested that there was need for more time to be allocated to peer teaching activity. They said that there was need for a student teacher to be given full hour to teach thereby giving him/her time to deliver a full lesson and allow time for peers to comment and ask questions. They complained that the current 10-15 minutes was not enough and no meaning practice took place. Further, they suggested that student teachers needed more than one teaching opportunity. All the respondents suggested between 2-3 teaching opportunities per student. In order for this to be realised, they suggested that peer teaching should be a full year exercise which could allow student teachers to have more than one opportunity to teach. According to respondents, lack of adequate time per lesson and having only one teaching opportunity account for the major weaknesses and reason why the current peer teaching exercise was weak and sometimes ineffective. For example, a student teacher said the following: "A student should be given full lecture (one hour) to teach...this can help in terms of evaluation, whether the subject content was successfully delivered to the learners or not". Another student teacher said: "other than having 2 or 3 students to teach within the same hour, it is better that only one student taught for the whole period so that more time is given to the teacher and the peers to contribute and ask questions". Another student teacher had the following to say "is as much as theory in teaching methodology is important, there is need to allocate more time for practical part such as peer teaching. Peer teaching should be done twice or thrice by each student". As hinted above, these responses attest to the fact that peer teaching as currently conducted has a number of weaknesses. These weaknesses have to be removed if the exercise s to (re)gain its usefulness.

In addition to suggesting how peer teaching can be improved, respondents suggested other strategies which could augment the current components of teacher preparation at the University of Zambia. The suggestions presented below are those teacher preparation practices which are currently not being implemented by the University of Zambia but respondents felt that they could help strengthen teacher preparation at the University.

Firstly, respondents suggested that there was need for student teachers to be attached to nearby secondary schools. The idea is that students could go to these schools to observe experienced teachers teach and learn from them. Further, they could also participate with the guidance of an experienced teacher in the handling of the lesson. After observing a few lessons, a student teacher could be allowed to teach even one lesson to have a practical experience of teaching in a real classroom environment. One teacher educator stated that even if student teachers only went to these schools to observe without necessarily to teach, they would still learn a lot on how one can deliver a lesson. Respondents added that attaching student teachers to nearby schools would also mean that a teacher preparation institution and a secondary school were working in collaboration in teacher preparation. This would help student teachers identify relationships between what goes on in a training programme and what they were prepared to do in a secondary school. One student said "attachment to some nearby schools is needed so that the students have the actual feel of a classroom and hence build the required strategies. As such, peer teaching would also reflect the rightful learners who are the people we will teach". This response also suggests that having peer teaching where student teachers teach each in simulation activities is weak and that it should be augmented by teaching in a real classroom environment and teach authentic pupils at the level of the lesson to be delivered. When asked what other practical activities could enhance student teachers' practical abilities, one teacher educator stated:

something that quickly comes to my mind, we can attach them to schools around UNZA (University of Zambia). We have Munali Boys, Munali Girls, Kabulonga Boys, Kabulonga Girls, Olympia, Northmead, Roma. And these are big schools. We attach them and we include that on the time table. Schools can welcome them and give them tasks. On a particular day, they observe a lesson, help with marking or they teach on another day while an experienced teacher is observing". That way, they become sharper than just doing peer teaching here on campus.

From this response, it is evident that both teacher educators and student teachers agreed that student teachers' attachment to secondary schools before they went for school teaching experience may prove helpful in developing and improving teaching skills learnt in the University. Note that this activity would not be a replacement for peer teaching but an additional practical activity. This activity appears 
effective to counteract the weakness of peer teaching where it is criticised for its artificiality and that the teaching environment is not authentic. Thus, attaching student teachers to schools and participate in teaching can be an effective tool to practice teaching in a real classroom environment where learners are performing their real life roles as learners.

Another strategy suggested was the use of videos to student teachers. Respondents suggested that there was need to have videos of experienced teachers teaching in a real classroom situation. Teacher educators would use these videos as examples of how one can teach. Through the videos, the student teachers would learn how to deliver content and with which methods as well as general class management. Time management is one the benefits student teachers would learn from such videos. Since teaching is contextual and there are disparities between rural and urban schools, respondents further suggested that there was need for a variety of videos. Some videos should be about a rural school, others about an urban school. Further, some videos would be about a male teacher while other should be about a female teacher. This strategy was suggested by both teacher educators and student teachers. For example, one student teacher said "we need videos just to see how to teach. We can learn alot from videos other than just explaining theoretically in lectures". On the same point, one teacher educator had the following to say:

Showing videos of how a class is conducted. This can help them (student teachers)... show them a video how teachers teach a real class. The lessons should be urban based and rural based schools and capture differences. Capture teachers using different methods and ask students (trainee teachers) to analyse or hold a discussion or write an assignment based on what they have seen in the video".

Finally, respondents observed that weak preparation of teachers with practical skills was because the school of education was running like any other school of the University. They observed that depending on lecturers from other schools to teach content and to follow the academic calendar resulted into students receiving content that was not tailored towards teaching and having short teaching practice. Thus, they suggested that the school of education needed to run as an independent faculty but still operate under the general administration of the University. Respondents further explained that having the school of education run as an institute would mean that decisions about the length of teaching practice/experience would be decided by the institute without interfering or being interfered by the general university calendar. One student teacher said " Teaching practice is very short because we are rushing to come back. And now, we were forced to go when schools were on holiday because that's when UNZA closed. I think the best is for school of education to be independent". Two teacher educators stated the following respectively:

\begin{abstract}
School of education should be a professional school. Teaching practice is supposed to be for three months and peer teaching more than once....two or three times is better... you can't blame the students (for not being able to teach), the problem is with the system. Even me, I did it for 15 minutes, so even lecturers have those gaps (practical skills). The university should not decide everything for school of education. So, we are just theoretical.
\end{abstract}

If the school of education is running as an institute, we can even decide to start exposing students to school starting from second year because we can decide how to improve their teaching skills. But now, we can't do that because they may be away while their friends from other schools are learning. And according how things are, they are supposed to be learning every time also.

These findings seems to agree with what Manchishi and Mwanza (2013), Manchishi and Masaiti (2011) and Mulenga and Luangala (2015) established about teacher preparation at the University of Zambia where they established that the school of education reliance on other schools to teach content often resulted into school of education student receiving subject content which was not appropriate to the needs of a secondary school teacher. Mulenga et 1 (2015) further argued that teacher education programme at UNZA was not responsive to the needs of secondary schools. Mwanza (2016) also reported that the short period of teaching practice and lack of adequate opportunities for peer teaching resulted into inadequate teacher preparation at the University of Zambia. It is not surprising therefore, that respondents in this study suggested that one way to solve the problem is to make the school of education run as an institute where decisions about how to prepare teachers can be made by members of the institute and not the mainstream University. 


\section{CONCLUSION}

This study attempted to answer the question of whether or not peer teaching was still a useful strategy in teacher training at the University of Zambia. Based on the data from interviews with teacher educators and student teachers, the study has established that there is no consensus among respondents as to whether it was useful or not. While some respondents argued that it was useful or effective, others said it was not. However, to conclude on the subject, it would be helpful to quote one respondent who stated "peer teaching is very important and if it can be done correctly, it can be very effective". This means that while peer teaching is a useful technique in University of Zambia teacher preparation programme, it was faced with a number of challenges and inconsistencies which had to be rectified if student teachers and teacher educators were to truly benefit from the benefits of peer teaching. Finally, the study has provided suggested additional practical steps which may be taken to enhance teacher preparation such as the use of videos and students attachment to nearby schools.

\section{REFERENCES}

Allen, D. (1967, September). Microteaching, a description. ERIC document (ED 019 224). Retrieved from http://files.eric.ed.gov/fulltext/ED019224.pdf

Allen, D., \& Eve, A. (1968, December). Microteaching. Theory into Practice, 7(5), 181-185. Retrieved from http://www.jstor.org/stable/1475985?seq=1.

Allen, R.M. \& Casbergue, R.M. (1997). Evolution of novice through expert teachers' recall: implications for effective reflection on practice. Teaching and Teacher Education, 13. (7), 741755.

Amobi, F. A. (2005). Preservice teachers' reflectivity on the sequence and consequences of teaching actions in a microteaching experience. Teacher Education Quarterly 32(1), 115-130.

Arends, R.I. (2000). Learning to Teach. Newyork: Mc Graw-Hill.

Bakir, S. (2014). The Effect of Micro Teaching on the Teaching Skills of Pre Service Science Teachers. Journal of Baltic Science Education, 13, (6), 789-801.

Bean, T. W. \& Stevens, L.P. (2002). Scaffolding Reflection for Pre-service and Inservice Teachers, Reflective Practice, 3,(2), 205-214.

Beattie, M. (1997). Fostering reflective practice in teacher education: inquiry as a framework for the education of a professional knowledge in teaching. Asia-Pacific Journal of Teacher Education, 25(2), 111-129.

Benton-Kupper, J. (2001). The microteaching experience: Student perspectives. Education, 121(4), 830-835.

Bradford-Watts, K. (2011). Students teaching students? Peer teaching in the EFL classroom in Japan. THE LANGUAGE TEACHER Online »<jalt-publications.org/tlt>.

Burns, N., \& Grove, S.K. (2003). Understanding nursing research (3rd ed.). Philadelphia:W.B. Saunders Company.

Çakır, Ö. (2000). Ogretimen Yetistirmede Teoriyi Pratige Baglayan Mikroogretimim Turkiye deki Durumu: UC Universite Hacettepe Universitesi Egitim Fakultesi Dergisi, 18, 62-68.

Cimer, A, Cimer, S.O and Vekli, G.S. (2013). How does Reflection Help Teachers to Become Effective Teachers?. International J. Educational Research, 1 (4), 2306-7063.

Demerel. (2004). Yabanci Dil Ogretimi Dil Pasaporu, Dil Biyografisi, Dil Dosyasi. Ankara: Pegen Yagincilik.

Conway, P.F. (2001). Anticipatory reflection while learning to teach: from a temporarily truncated to a temporarily distributed model of reflection in teacher education. Teaching and Teacher Education, 17, 89-106.

Courneya, C.A., Prat, D.D., \& Collins, J. Through What Perspective Do We Judge the Teaching of Peers? Teaching and Teacher Education, 24(1), 69-79.

Creswell, J.W. (2003). Research design: Qualitative, quantitative, and mixed methods approaches. Thousand Oaks, CA: Sage Publications.

Cruickshank, D. R., et al. (1996). Preparing Americaee Teachers. Bloomington, IN: Phi Delta Kappa.

Freese, A.R. (2006). Reframing one's teaching: Discovering our teacher selves through reflection and inquiry, Teaching and Teacher Education 22:100-119. 
Holloway, I. (1997). Basic concepts for qualitative research. Wiley-Blackwell.

Ismail, S.A.A (2010). Student Teachers ${ }^{e e}$ Microteaching Experiences in a Pre-service English Teacher Education Program. Journal of Language Teaching and Research, 2 (5), 1043-1051.

Kalkowski, P. (2001). Peer and cross-age tutoring. Northwest Regional Educational Laboratory School Improvement Research Series. Retrieved from <nwrel.org/scpd/sirs/9/c018.html>.

Kavanoz, S. H. and Yuksel, G (2010). An Investigation of Peer-Teaching Technique in Student Teacher Development. The International Journal of Research in Teacher Education 1(Special Issue): 0-19.

Latham, B. (2007). Sampling: What is it?. Quantitative Research Methods, ENGL 5377.

Manchishi, P. C. And Masaiti, G. (2011). The University of Zambia pre-service teacher programme: Is it responsive to schools and communities ${ }^{\text {ee }}$ aspirations? European Journal of Educational Studies, 3(2), 311-324.

Manchishi, P. C. and Mwanza, D. S. (2013). The University of Zambia School Teaching Experience: Is it effective? Journal of Excellence in Higher Education, 4 (2), 61-77.

Mulenga, I.M. and Luangala, J.R.(2015). Curriculum Design in Contemporary Teacher Education: What Makes Job Analysis a Vital Preliminary Ingredient?. International Journal of Humanities Social Sciences and Education (IJHSSE), 2 (1),39-51.

Murtiana, R. (2012, November). A journey of a thousand miles of future teachers begins from a single step in a microteaching class. Paper presented at the 6th International Seminar of Research in Teacher Education: What, How, and Why? (pp. 459-476). Salatiga City, Java, Indonesia.Retrieved from http://repository.library.uksw.edu/bitstream/handle/123456789/2709/ PROS_Rahmila\%20Murtiana_A\%20Journey\%20of\%20a\%20Thousand\%20Miles_full\%20text.p df? sequence $=2$.

Mwanza, D.S. (2016). A Critical Reflection on Eclecticism in the Teaching of English Grammar in Selected Zambian Secondary Schools. Unpublished PhD Thesis. University of Western Cape, South Africa.

Ogeyik, M. C. (2009). Attitudes of the student teachers in English language teaching programs towards microteaching technique. English Language teaching, 2(3), 205-212.

Stanley, C. (1998). A framework for teacher reflectivity, TESOL Quarterly 32 (3), 584-591

Patton, M. Q. (2002). Qualitative research and evaluation methods (3rd ed.). Thousand Oaks, CA: Sage Publications, Inc.

Polit, D.F. and Hungler, B. P. (1999). Nursing research principles and methods. Philadelphia: Lippincott Williams.

Ralph, E.G. (2014). The Effectiveness of Microteaching: Five Years' Findings. International Journal of Humanities Social Sciences and Education (IJHSSE), 1(7) 17-28.

Tobias, S. (1979). Anxiety research in educational psychology. Journal of Educational Psychology, 71, 573-582.

Trott, A. (1976). Microteaching: An Overview. London: Educational Media International.

Wilkins, E., Shin, E., \& Ainsworth, J. (2009, Spring). The effects of peer feedback practices with elementary education teacher candidates. Teacher Education Quarterly, 36(2), 79-93. Retrieved from http://www.jstor.org/stable/23479253?seq=2.

White, C.J. (2003). Research Methods and Techniques. Pretoria: Mustung.

Yeany, R. (1978). Effects of microteaching with videotaping and strategy analysis on the teaching strategies of preservice science teachers. Science Education, 62 (2), 203-207. 


\section{AUTHORS' BIOGRAPHY}

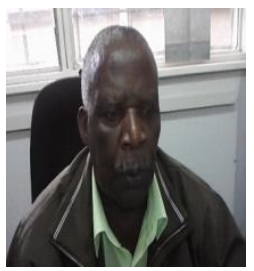

Dr. Peter Chomba Manchishi, is a Senior Lecturer in the Department of Language and Social Sciences Education, in the School of Education at the University of Zambia. He holds a PhD, MA and BA in Applied Linguistics from the University of Franche-Comté at Besancon in France. He also has a Diploma in Education from Nkrumah Teachers' College. His research interests are in Language and teacher education.

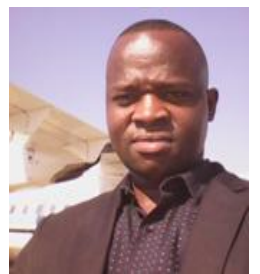

Dr. David Sani Mwanza, is a Lecturer of English Teaching Methods at the University of Zambia. He obtained a $\mathrm{PhD}$ in Linguistics from the University of Western Cape in South Africa. His Master and Bachelor's Degrees were both obtained from the University of Zambia. His research interests include Teacher education, language teaching and Multilingual Education. 